\title{
EFEKTYWNOŚĆĆ E-NAUCZANIA W SZKOLNICTWIE WYŻSZYM. STUDIA PRZYPADKÓW
}

\author{
Abstract \\ EFFECTIVENESS OF TEACHING IN E-LEARNING SYSTEM IN HIGHER \\ EDUCATION. CASE STUDIES
}

The popularity of using e-learning in higher education in Poland is insufficient. The lecturers have doubts about the effectiveness of this way of teaching. In this article, the author presents examples of conducting classes in the blended learning formula along with the results of surveys, conducted among PhD students learning specialist English in the remote formula. Education in the social sciences is based on the practice orientation, transfer of specific skills, working in groups (e.g. editorial), discovering creativity through case studies. However, it is necessary to strengthen the trust in online learning, as well as to learn compulsory and verify learning on a regular basis. The basis is proper motivation of students to study and regularity of work using the elements of remote teaching.

Key words: e-learning, media education, blended learning, social science

Kształcenie w zakresie nauk społecznych opiera się na nastawieniu na praktykę, pracy w grupach (np. redakcyjnych), odkrywaniu kreatywności poprzez działania bazujące na studiach przypadków czy design thinking. Niezbędne jest jednak wzmocnienie zaufania do nauki online i weryfikacja efektów kształcenia na bieżąco przez samych studentów i wykładowców.

Celem artykułu jest przedstawienie dwóch popularnych platform e-learningowych, które autorka wykorzystuje w praktyce nauczania, oraz stosowanych technik pracy ze studentami w formule zdalnej, a także wyników badania ankietowego przeprowadzonego wśród doktorantów z zakresu nauk o mediach na Wydziale Politologii UMCS. Na przykładzie zajęć między innymi ze specjalistycznego języka 
angielskiego, prowadzonych $\mathrm{w}$ formule zdalnej, i analizy badania ankietowego wnioskuje się o efektywności blended learningu/e-learningu w szkolnictwie wyższym (ze szczególnym uwzględnieniem nauk społecznych).

Dzięki e-learningowi możliwe jest nauczanie efektywnej pracy grupowej z wykorzystaniem różnorodnych narzędzi związanych z mediami społecznościowymi. Proces nauczania staje się elastyczny, ale wymagający systematyczności. W e-learningu konieczne jest wprowadzenie odpowiednich narzędzi wspierających ten sposób edukacji, przynajmniej podstawowej wiedzy na temat ICT oraz możliwości korzystania z platform nauczania, najlepiej także w wersji mobilnej. Środowisko studenckie, które jest ciekawe innowacyjnych metod kształcenia, potrafi samodzielnie się uczyć, poszukiwać źródeł informacji.

Platformy e-learningowe mają być specyficznym centrum kształcenia, które daje możliwości na przykład przesyłania bieżących informacji pomiędzy grupami projektowymi. Konieczne jest jednak przygotowanie odpowiednio ustrukturalizowanych, usystematyzowanych materiałów dydaktycznych, wcześniejsze ich przetestowanie, wprowadzenie przynajmniej częściowego, zautomatyzowanego systemu oceny ${ }^{1}$. Dzięki platformom e-learningowym można wprowadzić na zajęciach najnowsze materiały dydaktyczne z różnych źródeł, również $\mathrm{w}$ formie multimedialnej. Możliwe jest też stałe wspieranie uczących się przez wykładowcę, bezpośredni kontakt online, bieżący nadzór nad systematyczną pracą studentów. Dzięki aplikacjom dydaktycznym można nauczyć się nawyku poszukiwania innych sposobów wykonywania zadań. Innowacyjne narzędzia edukacyjne poszerzają horyzonty myślowe studentów. Zajęcia z wykorzystaniem ICT i blended learningu powinny być obowiązkowe (lub przynajmniej uzupełniające) we współczesnym systemie edukacyjnym². Większość polskich uczelni wyższych posiada odpowiednie systemy informatyczne, umożliwiające prowadzenie kursów e-learningowych. Jednak jak zauważają Krzysztof Redlarski i Igor Garnik, nadal w szkolnictwie wyższym istnieją czynniki ograniczające ich wykorzystanie, takie jak²:

- brak odpowiednio wdrożonego systemu szkoleń wśród osób prowadzących kursy;

${ }^{1}$ G. Ubachs, E-xcellence. Quality Assessment for E-learning: A Benchmarking Approach, EADTU, Heerlen 2012, s. 58-64.

2 Zob. np. A. Stecyk, Abc eLearningu: system LAMS (learning activity management system), Centrum Doradztwa i Informacji Difin, Warszawa 2008; M. Dąbrowski, E-learning w szkolnictwie wyższym, „Studia BAS” 2013, nr 3 (35); M. Hyla, Przewodnik po e-learningu, Wolters Kluwer, Warszawa 2016; Z. Zieliński, E-learning w edukacji. Jak stworzyć multimedialna i w petni interaktywna treść dydaktyczna, Helion, Gliwice 2015; I. Mokwa-Tarnowska, E-learning i blended learning w nauczaniu akademickim: zagadnienia metodyczne, Wydawnictwo Politechniki Gdańskiej, Gdańsk 2015; D.R. Garrison, N.D. Vaughan, Blended Learning in Higher Education: Framework, Principles, and Guidelines, Jossey-Bass, San Francisco 2008.

${ }^{3}$ K. Redlarski, I. Garnik, Zastosowanie systemów e-learningu w szkolnictwie wyższym, [w:] B.A. Basińska, I. Garnik (red.), Zarządzanie informacyjnym środowiskiem pracy, Wydział Zarządzania i Ekonomii Politechniki Gdańskiej, Gdańsk 2014, s. 77-94. 
- brak umiejętności i wiedzy części pracowników uczelni w zakresie tworzenia atrakcyjnych form prezentacji materiałów, skutkujący trudnościami w opracowaniu interaktywnych i multimedialnych materiałów dydaktycznych.

\section{Platforma Edmodo}

$\mathrm{W}$ trakcie zajęć z zakresu mediów lokalnych, ekonomiki mediów (dziennikarskie uzupełniające studia magisterskie), public relations (studia licencjackie) i specjalistycznego języka angielskiego (studia doktoranckie z zakresu nauk o mediach) autorka wykorzystuje między innymi Edmodo, amerykańską platformę e-learningową, która powstała w 2008 roku. Jej współzałożycielami są Nic Borg i Jeff O’Hara, pracownicy San Mateo High School w Kalifornii (USA). Na platformie zarejestrowanych jest ponad 300 tysięcy placówek edukacyjnych. System służy wymianie specjalistycznej wiedzy pomiędzy dydaktykami, dzieleniu się pomysłami i narzędziami. Edmodo to jednak nie tylko baza materiałów (nazwana Spotlight), ale przede wszystkim miejsce umożliwiające bieżący kontakt nauczyciela ze słuchaczami/ studentami.

System umożliwia przesyłanie materiałów poszczególnym klasom/grupom zajęciowym, a wykładowca może indywidualnie oceniać każdego studenta/ucznia między innymi dzięki systemowi specjalnych odznak (badges). Dostęp do poszczególnych kursów/grup jest możliwy po wpisaniu automatycznie wygenerowanego kodu grupowego. Wiele przycisków, które umieszczono obok nazwisk członków grup, służy na przykład do określenia ich przywilejów. Możliwe jest dowolne zarządzanie widokami, które będą dostępne dla poszczególnych studentów. Uprawnienia nauczyciela dotyczą również moderacji postów zamieszczanych na głównej tablicy grupy. Przy nazwisku studenta znajduje się mała koperta, gdy podczas rejestracji podał on swój adres e-mail. To oznacza, że członek naszej grupy otrzymuje powiadomienia o działaniach na Edmodo w formie komunikatów na jego adres mailowy. Bardzo ważne jest także to, że korespondencja między studentem a wykładowcą pozostaje całkowicie poufna. Rozwiązania zadań widzi tylko nauczyciel, co bardzo ułatwia pracę z nieśmiałymi uczniami/studentami. Również korespondencja dotycząca oceny wykonanych ćwiczeń (w formie opisowej i punktowej) widoczna jest tylko na profilu konkretnego słuchacza i w panelu wykładowcy.

Edmodo oferuje dwa typy komunikowania się: bezpośrednie, czyli realizowane poprzez notatki na stronie głównej i w grupie, oraz indywidualne, kierowane do wybranej grupy odbiorców (w podgrupach) lub jako prywatne wiadomości. $\mathrm{Na}$ platformie można dodać plik z komputera, załączyć link, ewentualnie dołączyć element już wcześniej umieszczony we własnej bibliotece Edmodo. Każdą wiadomość można opublikować natychmiast lub ustawić dzień jej wyświetlenia. 
W ramach Edmodo możliwe jest tworzenie zadań otwartych lub quizów, czyli testów, w ramach których aktywne są zadania typu: wybór jednego z wielu możliwych, prawda/fałsz, krótka odpowiedź, uzupełnienie luk i dopasowywanie. Poza poleceniem krótkiej odpowiedzi wyniki sumują się automatycznie. Rolą nauczyciela jest wyłącznie ocena zadań otwartych.

Platforma ma jeszcze wiele funkcji bardzo przydatnych dydaktykom. Można na przykład zamieszczać swoje materiały w serwisie Spotlight, wykorzystywać do własnych zajęć artykuły udostępnione przez innych dydaktyków (większość zasobów jest bezpłatna) ${ }^{4}$.

\section{Platforma Moodle}

Autorka stworzyła ponadto kurs z zakresu public relations i marketingu medialnego na platformie Moodle. Szkolenie składa się z wykładów, prezentacji, ale także quizów, bezstresowych sprawdzianów, krzyżówek czy elementów pobranych z Wikipedii. Podczas zajęć prowadzonych $\mathrm{w}$ formule wykładu konwersatoryjnego $\mathrm{z}$ public relations uzupełniająco stosowane są też warsztaty i ćwiczenia zamieszczona na platformie Moodle. Jest to w pełni funkcjonalna, bardzo elastyczna platforma nauczania open source (znana również jako Learning Management System lub Virtual Learning Environment). Moodle jest obecnie używany przez ponad 70 milionów użytkowników na całym świecie, a został stworzony w 2001 roku przez Martina Dougiamasa, który chciał zapewnić nauczycielom efektywne narzędzia do zaangażowania studentów/uczniów w aktywne uczenie się online. Moodle współpracuje z globalną siecią certyfikowanych partnerów, programistami i nauczycielami z całego świata, aby wspierać szybko rozwijającą się społeczność użytkowników platformy ${ }^{5}$.

Moodle pozwala na założenie własnych szkoleń oraz dokładne określenie ról i uprawnień do zasobów poszczególnych kursów. Można więc być tylko gościem, studentem, nauczycielem bez praw edycji, prowadzącym kurs, autorem szkolenia lub administratorem. W przypadku tej ostatniej roli chodzi o administrowanie pracą platformy i na przykład ewentualne zmiany uprawnień użytkowników kursów.

Obsługa szkoleń zakładanych na platformie jest dość intuicyjna i obejmuje w pierwszej kolejności formaty dostarczania treści kursów. Dzięki temu możemy wybrać ustawienia zadań do wykonania w formacie tygodniowym, tematycznym (bez ścisłych ram czasowych) oraz towarzyskim (opartym np. na forum dyskusyjnym). Standardowe części kursu zakładanego na platformie Moodle obejmują przykładowo ankiety wykorzystywane podczas ewaluacji procesu dydaktycznego

${ }^{4}$ Na podstawie materiałów Ambasadora Edmodo zamieszczonych na stronie: www.edmodo. com (autorka od 2017 roku jest ambasadorem Edmodo).

${ }^{5}$ Zob. https://moodle.org/ (dostęp: 10.05.2018). 
przebiegającego $\mathrm{w}$ formule online, a także chat umożliwiający przeprowadzanie synchronicznych dyskusji. Natomiast w dzienniku rejestrowane są postępy słuchaczy, korespondencje między uczniem i nauczycielem oraz wystawiane oceny. Bardzo ważne jest też forum dyskusyjne, które pozwala na komunikację asynchroniczną pomiędzy uczestnikami szkolenia $\mathrm{w}$ różnorakich formułach (np. z komunikatami przesyłanymi na pocztę e-mail, załącznikami, nauczyciel może również zapisać do subskrypcji informacji zamieszczanych na forum całą swoją grupę). Nie można także pominąć opcji głosowania, dzięki czemu możliwe jest szybkie przeprowadzenie ankiety z podanymi przez wykładowcę odpowiedziami do wyboru oraz quizu, który umożliwia tworzenie testów składających się z zadań wielokrotnego wyboru. Ciekawa jest funkcja „Warsztaty”, dzięki której możliwa jest praca w grupach w różnych konfiguracjach oraz wzajemne ocenianie swoich prac przez uczestników szkolenia. Z kolei „Wiki” to miejsce do grupowego tworzenia dokumentów przy użyciu przeglądarki internetowej. Trzeba jednak zaznaczyć, że wszelkie zmiany na serwerze Wiki są odwracalne, można też ograniczyć uczniom możliwości edycji poszczególnych haseł. Natomiast opcja „Zadanie” umożliwia przesyłanie różnego typu prac projektowych czy raportów bezpośrednio na platformę lub do prowadzącego zajęcia. Dzięki tej funkcji efekty projektów można przesyłać online lub offline ${ }^{6}$. System Moodle jest zgodny ze standardem Sharable Content Object Reference Model, co pozwala na tworzenie własnych atrakcyjnych materiałów (np. testów) w niezależnych narzędziach obsługujących ten standard ${ }^{7}$.

\section{Przykładowe zastosowania blended learningu}

Przez trzy lata autorka prowadziła ćwiczenia ze specjalistycznego języka angielskiego dla doktorantów z zakresu nauk o mediach $\mathrm{z}$ wykorzystaniem blended learnin$g u$ i bezpłatnych, internetowych aplikacji dydaktycznych. Dodatkowo wprowadzono blended learning na zajęciach z zakresu public relations, ekonomiki mediów oraz mediów lokalnych. W trakcie wykładów konwersatoryjnych i ćwiczeń stosowano elementy design thinking (początkowe etapy procesu przeprowadzono $\mathrm{w}$ trakcie zajęć stacjonarnych), pracy projektowej, redakcyjnej (z podziałem na konkretne funkcje i związane z nimi obowiązki).

$\mathrm{W}$ ramach zajęć $\mathrm{z}$ public relations wdrożono między innymi pracę grupową nad projektami własnych firm (lub aktualnie istniejących przedsiębiorstw, których strategia PR wymaga modyfikacji), pisano informacje PR, stworzono projekty gazet public relations czy kampanii społecznych. Poszczególne etapy prac były

${ }^{6}$ S. Szabłowski, E-learning dla nauczycieli, Wydawnictwo Oświatowe FOSZE, Rzeszów 2009, s. 99-107; M. Susfał, Moodle: ćwiczenia praktyczne. Doceń e-learning z platforma Moodle, Helion, Gliwice 2013, s. 15-20.

7 Zob. https://moodle.com/about/ (dostęp: 10.05.2018). 
ilustrowane za pomocą aplikacji służących do tworzenia memów czy plakatów. Część projektów była realizowana na platformie Edmodo. Dodatkowo zagadnienia teoretyczne zostały udostępnione na platformie Moodle. Zajęcia przeprowadzono bardzo sprawnie, wszystkie prace oddawano bez zbędnych opóźnień. Najlepsze, innowacyjne rozwiązania projektów były publikowane na stronie Facebooka kierunku dziennikarstwo i komunikacja społeczna UMCS.

$\mathrm{Z}$ kolei podczas zajęć $\mathrm{z}$ ekonomiki mediów projektowano własne firmy medialne, konstruowano biznesplany, planowano kampanie marketingowe, tak by utrzymać swoje produkty medialne na rynku przynajmniej przez rok. Także w tym przypadku część zajęć odbywała się na platformie Edmodo, w formie pracy indywidualnej i grupowej. Efektem wykładu konwersatoryjnego były koncepcje własnych wydawnictw prasowych czy koncernów medialnych, które powstały w wyniku konsultacji i stałej pracy (poza standardowymi zajęciami) na platformie e-learningowej.

Natomiast zajęcia z mediów lokalnych odbywały się w dość małym procencie na platformie e-learningowej, jednak część materiałów uzupełniających wykłady była zamieszczona w Edmodo. Dzięki temu studenci mogli samodzielnie uzupełniać wiedzę z wykorzystaniem wielu materiałów multimedialnych, których pokazanie w trakcie standardowych zajęć nie zawsze było możliwe (chociażby z powodu ograniczeń czasowych).

Autorka w największym stopniu zastosowała blended learning na zajęciach ze specjalistycznego języka angielskiego dla doktorantów w zakresie nauki o mediach. $\mathrm{Na}$ bieżąco zamieszczała artykuły do tłumaczenia $\mathrm{z}$ języka angielskiego na polski (lub odwrotnie), prosiła o umieszczanie komentarzy do tekstów anglojęzycznych dotyczących na przykład public relations, edukacji medialnej czy etyki w nauce. Dodatkowo wykorzystywano narzędzia do tworzenia plakatów, memów czy chmur wyrazów, dzięki którym można szybciej opanować trudniejsze słówka.

Bardzo dobrym wzmocnieniem nauki w formule e-learningowej okazało się przyznawanie odznak pod koniec każdego semestru pracy (zajęcia z języka angielskiego na studiach doktoranckich prowadzone są przez trzy lata). Stworzone przez autorkę graficzne formy docenienia pracy stały się dodatkowym elementem motywującym do systematycznej pracy na platformie Edmodo.

\section{E-learning w dydaktyce szkół wyższych w zakresie nauk społecznych. Wyniki badań ankietowych}

Podsumowując trzy lata prowadzenia zajęć z zakresu specjalistycznego języka angielskiego na studiach doktoranckich w maju 2018 roku, autorka przeprowadziła wśród 20 doktorantów (często samodzielnie prowadzących już zajęcia) ankietę dotyczącą efektywności blended learningu i e-learningu w naukach społecznych. Ankietowani spojrzeli na zdalne nauczanie z pozycji studenta oraz wykładowcy. 
Według ankietowanych e-nauczanie daje dużo innowacyjnych opcji z racji możliwości wykorzystania narzędzi internetowych.

Z perspektywy studenta mogę powiedzieć, że to przede wszystkim pobudza kreatywność, czytanie długich tekstów i ich omawianie jest mniej ciekawe niż wykorzystywanie np. jakichś programów do tworzenia kreatywnych podsumowań, pisania wniosków etc. Chodzi po prostu o to, że mózg się nie wyłącza, a takie bodźce go pobudzają. Zaleta to oszczędność czasu, mam na myśli możliwość wykonywania zadań, uczestniczenia w zajęciach niemal wszędzie, gdzie tylko mamy dostęp do sieci. To prawdziwy lifesaver, jeśli chodzi o sytuacje, gdzie z zajęciami na uczelni kolidują inne zobowiązaniå .

Ankietowana przyznała, że z perspektywy wykładowcy nie stosuje zbyt wielu elementów e-learningu. Korzysta natomiast z pomocy audiowizualnych, prezentacji, filmów, filmików, memów, casów z social mediów i dzięki temu osiąga bardzo dobre efekty w nauczaniu. „Stosowanie TIK pobudza myślenie, wyklucza znudzenie, wzmaga kreatywność" 9

Kolejny ankietowany akcentował, że warto stosować blended learning również w nauczaniu przedmiotów z zakresu nauk społecznych. Kiedy student widzi kreatywne przygotowanie prowadzącego, sam odpłaca się tym samym. Studenci wyjątkowo cenią sobie wiedzę praktyczną i doświadczenie, które także można przedstawiać za pomocą narzędzi e-learningowych ${ }^{10}$.

Z perspektywy studenta sam e-learning wydaje się mieć mniejszą skuteczność niż zajęcia kontaktowe. Oczywiście jest łatwiejszy, zwłaszcza dla osób, które mieszkają daleko od uczelni. Dodatkowo nacisk jest kładziony na samodzielną pracę studenta, co sprowadza się też do systematyczności. Kontakt bezpośredni z wykładowcą pozwala na zadawanie dodatkowych pytań, branie udziału w dyskusjach i (poza zdobywaniem wiedzy) rozwijanie umiejętności interpersonalnych. „Osobiście lubię metodę blended learningu, bo pozwala na oszczędność czasu na dojazdy, wygodę w zarządzaniu czasem (sama decyduję, w którym momencie w ramach czasu określonego przez wykładowcę zrobię materiał) i w szczególności osobom pracującym pozwala rozwijać swoje wykształcenie"11.

Inny doktorant uważa, że metoda e-learningu zdecydowanie powinna być stosowana $\mathrm{w}$ przedmiotach $\mathrm{z}$ zakresu nauk społecznych w szkolnictwie wyższym. Jej główne zalety to: dostęp do zasobów wiedzy w każdym miejscu i czasie (pod warunkiem posiadania Internetu); nauka samodzielności, szukania wiedzy, dociekliwości; możliwość powrotu do już przeczytanego materiału; wiedza może być przekazywana w różnych formach (materiałów pisanych, wideo, audio), co ułatwia jej zrozumienie i zapamiętanie. Wadą $\mathrm{w}$ przypadku nauk społecznych może być brak dyskusji (chyba że zajęcia będą prowadzone w czasie rzeczywistym lub istnieje

\footnotetext{
8 Ankieta nr 5.

9 Tamże.

10 Ankieta nr 11.

11 Ankieta nr 15.
} 
możliwość wypowiadania się na forum pod wątkiem). Dużo zależy od samych prowadzących zajęcia, od ich umiejętności technicznych oraz chęci indywidualnego podejścia do studenta, co z pewnością zajmuje więcej czasu niż w przypadku zajęć tradycyjnych ${ }^{12}$.

Ankietowani uważali także, że efektywność e-nauczania w szkolnictwie wyższym jest ściśle związana $\mathrm{z}$ doborem odpowiednich narzędzi i metod czy materiałów. Właściwe dobranie środków to konieczna podstawa efektywnego korzystania z e-nauczania. Jest to technika bardzo przydatna i potrzebna we współczesnym szkolnictwie wyższym. Metoda e-learningu może być z powodzeniem wykorzystywana w przedmiotach z zakresu nauk społecznych. Szczególnie odnosi się to do zagadnień związanych z cyfryzacją nauk humanistycznych i nabywaniem umiejętności korzystania z zasobów sieci ${ }^{13}$.

E-learning bezpośrednio odnosi się do idei samokształcenia i samodoskonalenia studentów. Z perspektywy studenta tego typu narzędzia pozwalają na mobilne prowadzenie procesu edukacji i otwierają nowe możliwości dialogu bądź dyskusji. Z kolei z perspektywy wykładowcy akademickiego e-learning czy blended learning umożliwiają szersze prezentowanie wybranych materiałów, dają sposobność wprowadzania bieżących uzupełnień. Możliwe jest także stosowanie aktywizujących metod kształcenia i prowadzenia grupy w sposób jednolity (nieobecność na zajęciach stacjonarnych może zostać nadrobiona przy użyciu platformy internetowej). Niektóre zagadnienia, przykładowo odnoszące się do mediów społecznościowych, powinny być analizowane przy użyciu e-learningu i blended learningu. Nauki społeczne wkraczają także w swoją wersję 2.0, przez co tego typu narzędzia stają się jeszcze bardziej wartościowe w procesie edukacji ${ }^{14}$.

E-nauczanie w szkolnictwie wyższym jest koniecznością. Nie chodzi tylko o wprowadzanie pojedynczych aspektów kształcenia zdalnego przez wykładowców, na przykład poprzez korzystanie z platformy Edmodo.com, lecz o całościową zmianę obecnego nauczania. $\mathrm{Z}$ tego powodu blended learning wydaje się najodpowiedniejszym rozwiązaniem w nauczaniu w szkolnictwie wyższym ${ }^{15}$.

Doktoranci pisali również, że jeśli mówimy o naukach społecznych, a więc obejmujących społeczeństwo wraz $\mathrm{z}$ wewnętrzną strukturą i zmianami zachowań, to powinno być zupełnie naturalne, iż wraz z coraz większym użytkowaniem nowych technologii uniwersytet dostosowuje się do zmian. Nie chodzi jednak o wprowadzenie e-nauczania $w$ trakcie prowadzenia wszystkich zajęć, lecz o stworzenie takiej struktury, która w płynny sposób będzie odnosić się do nowych technologii i na nich bazować. Przykładowo można wprowadzić w trakcie studiów licencjackich jeden przedmiot podczas każdego semestru bazujący w całości na e-nauczaniu ${ }^{16}$.

12 Ankieta nr 19.

13 Ankiety nr 1, 2, 5, 8.

14 Ankiety nr 7, 10, 13, 14.

15 Ankieta nr 18.

16 Ankiety nr 3, 4. 
Opisując sytuację z perspektywy studenta, wdrażanie e-learningu jest bardzo istotne ze względu na podnoszenie szans na rynku pracy. Ważna jest nauka obecnych rozwiązań, narzędzi, oprogramowania. Aktualne kierunki społeczno-humanistyczne nie mogą pochwalić się największym szacunkiem wśród pracodawców. Stanowią raczej karykaturalną hybrydę, chcącą pokazać możliwości rozwoju po studiach, a jednocześnie nieuczącą studentów za pomocą nowoczesnych rozwiązań dydaktycznych. Dla osób niezajmujących się w późniejszym etapie pracą badawczą część zdobytej wiedzy jest zupełnie niepotrzebna. E-nauczanie może być więc szansą na polepszenie jakości nauczania dla studentów chcących efektywnie korzystać $\mathrm{z}$ nabytej wiedzy. Metodę e-learningu można z powodzeniem stosować w prowadzeniu kursów z obszaru nauk społecznych.

Z moich obserwacji wynika, że jednym z najważniejszych czynników związanych z efektywnością w tej formie nauczania jest wysoka motywacja studentów i studentek. Sam ukończyłem kilka takich kursów, prowadziłem też zajęcia e-learningowe. Dużym wyzwaniem w przypadku organizacji takich zajęć jest przygotowanie odpowiednich materiałów. Kursy online dają możliwość udostępnienia filmów, interaktywnych prezentacji czy nawet gier. Jednak nie każda osoba prowadząca ma możliwości lub umiejętności, aby przygotować nagrania, prezentacje na odpowiednio wysokim poziomie. Pojawia się tutaj kwestia zatrudnienia dodatkowych osób czy też zapewnienie odpowiedniego wynagrodzenia za przygotowanie treści kursów ${ }^{17}$.

Jedna z ankietowanych podkreśliła, że:

(...) w dobie wszechobecnych przekazów medialnych (zwłaszcza Internetu) e-learning jest dobrym pomysłem. Jest to spora oszczędność czasu, energii i głosu, jak również duże ułatwienie dla wykładowców o niskiej charyzmie i sile perswazji. Czasem lęk przed wystąpieniami publicznymi uniemożliwia pełne przekazanie wiedzy. Jednak nic nie jest w stanie zastąpić żywego kontaktu z człowiekiem, spotkania, żywej dyskusji. Często sam sposób bycia wykładowcy może być bardzo inspirujący, otwierający. Bywa też odwrotnie - sposób bycia wykładowcy może onieśmielać i zamykać studentów. Wydaje mi się, że jest to kwestia elastyczna i relatywna i powinna być wynikiem rozmowy ze studentami oraz zapoznania się z ich oczekiwaniami ${ }^{18}$.

Kolejna ankietowana uważa blended learning za bardzo przydatną metodę w szkolnictwie, nie tylko wyższym. Jest to nie tylko ukłon w stronę studentów, którzy z jakichś powodów nie mogą uczestniczyć w zajęciach, lecz również bardzo duża pomoc dla wykładowców. „Sama korzystałam z blended learningu na zajęciach fakultatywnych ze studentami II roku produkcji medialnej - nie zawsze ze względów zdrowotnych byłam w stanie dojechać na fakultet, ale ze wszystkim bardzo dobrze radziliśmy sobie zdalnie także na platformie Edmodo, dzięki czemu uniknęliśmy zaległości”" ${ }^{19}$.

\footnotetext{
17 Ankieta nr 6.

18 Ankieta nr 9.

19 Ankieta nr 16.
} 
Kolejny ankietowany stwierdził:

(...) oceniając e-learning z perspektywy ucznia, mogę powiedzieć, że system daje tyle, ile chce się z niego wziąć. W sprzyjających warunkach można poświęcić na zadanie dowolną ilość czasu w wybranym przez siebie momencie. Nie sądzę natomiast, by taki system mógł w pełni sprawdzić się w naukach społecznych, w tym w naukach o mediach, gdyż znacznie ogranicza pole do wymiany myśli, dyskusji, co w moim przekonaniu jest istotne. Należy zaznaczyć, iż w dużej mierze efektywność tego trybu zależeć będzie od rodzaju zajęć i tematyki przedmiotu. Zajęcia wykładowe mogą okazać się trudniejsze do przełożenia na e-learning w przeciwieństwie do ćwiczeń z zakresu mediów. W przypadku tworzenia kolejnych newsów, tekstów czy innych materiałów dziennikarskich system prawdopodobnie mógłby się sprawdzić. Wygodne umieszczenie dźwięków i obrazów, możliwość ingerencji nie tylko w tekst, ale także inne formaty, z których dziennikarstwo czerpie w naturalnych warunkach, może być rozwijające dla studentów i przygotowywać ich do zawodu. Z perspektywy wykładowcy mogę stwierdzić (przy niewielkim doświadczeniu), że dialog ze studentami jest bardzo różny - czasem dynamiczny i ciekawy, czasem sztywny i niedający spodziewanych rezultatów. Wobec tego brak interakcji na tym polu może nie być aż tak dużą stratą. Warto zastanowić się nad tym, co może być dla studentów korzystniejsze. Samodzielne wykonywanie zadań skłania do poszukiwań, refleksji, w odróżnieniu od tradycyjnych zajęć, kiedy zwykle student otrzymuje wiedzę od prowadzącego. Jak każdy system edukacyjny e-learning ma swoje minusy, ale ma też wiele plusów ${ }^{20}$.

Ankietowani uznali, że w obecnych czasach możemy zauważyć bardzo duży wpływ Internetu na życie ludzi, nie tylko tych młodych, ale także coraz częściej tych starszych. Da się to dostrzec na przykładzie rozwijającego się e-learningu. Czy taka forma nauki jest dobra? A może jest lepsza od obecnej wersji nauczania? Nie można jednoznacznie stwierdzić, która opcja ma więcej pozytywów.

Jak to wygląda z perspektywy wykładowcy? Plusem jest na pewno fakt, że studenci mają wszystko zebrane w jednym miejscu. Dla nas wygodne jest to o tyle, że nie dostajemy prac studentów w wersji papierowej, a co za tym idzie, nie ma ryzyka, że taka praca się zagubi albo student, wykorzystując naszą nieuwagę, będzie starał się nam wmówić, że na pewno oddał tę pracę. Mamy wszystko w wersji elektronicznej, nie ma potrzeby dźwigania stosu kartek papieru z wypracowaniami i zadaniami wykonanymi przez studentów. Również ocenianie jest wtedy płynniejsze. Atutem jest to, że studenci muszą pilnować terminów, gdyż po ich przekroczeniu mają niezaliczoną pracę. A co jest minusem? Na pewno fakt, że nie zawsze możemy sprawdzić rzetelność takich prac. Nie mamy pewności, że student nie przekopiował wszystkiego z Internetu, a także nie wiemy, ile było w tym wkładu własnego. Osobiście uważam, że plusów jest o wiele więcej aniżeli minusów, zarówno patrząc z perspektywy studenta, jak i wykładowcy. Trzeba tylko uważać, żeby dalej mieć kontakt ze studentami w realnym świecie. Jeśli wszystko jest używane w odpowiednich proporcjach, to na pewno takie platformy edukacyjne nie zaszkodzą, dodatkowo mogą mieć bardzo pozytywny wydźwięk w pracy ze studentami ${ }^{21}$.

\footnotetext{
20 Ankieta nr 12.

21 Ankieta nr 17.
} 
Kolejny ankietowany uważa, że skuteczność e-learningu zależy nie tylko od poziomu przygotowanych materiałów czy technik, ale w głównej mierze od stosunku do nauki samego uczącego się. Metody e-learningowe wymagają od studenta zaangażowania i chęci nauki, które przy tradycyjnych metodach mogą być łatwiej pobudzane przez nauczyciela. Skuteczność tych metod jest wysoka, ale tylko w przypadku, gdy student wykazuje chęć zdobywania wiedzy i przyswojenia materiału. Metody e-learningu z jednej strony dają wiele możliwości, z drugiej zaś mogą być źródłem wielu nadużyć. Od osoby uczącej się zależy to, czym będzie się kierować.

Jako osoba używająca od wielu lat metod e-learningu do uczenia się i rozwijania umiejętności językowych muszę stwierdzić ogromną skuteczność tych metod przy zaangażowaniu, a jednocześnie ogromne możliwości oszukiwania wszelakich platform i programów przy odrobinie chęci. W wypadku nauki ocenianej lub rzutującej na ocenę końcową może istnieć pokusa do nadużyć i zaangażowania osób trzecich. Jednak jest to problem, który pojawia się przy wszelkich sposobach nauczania. Jako wykładowca muszę stwierdzić, że e-learning wydaje się odpowiedni dla studentów, którzy wykształcili w sobie pewien rodzaj dyscypliny. Problematyczny wydaje się jednak w przypadku studentów młodszych lat. Nauki społeczne nie stanowią, moim zdaniem, wyjątku - ani pozytywnego, ani negatywnego. Metody e-learningowe mogą działać skutecznie wszędzie. Ale istnieją dwa warunki: odpowiednie dostosowanie sposobów do dziedziny i odpowiednie przystosowanie studentów to tej formy nauczania ${ }^{22}$.

Podsumowując, ankietowani przyznawali, że e-learning to dobre urozmaicenie dla studentów i dla nauczycieli. Z perspektywy wykładowcy e-learning to: dobre urozmaicenie; możliwość nadrobienia zajęć w trybie online; testowanie nowych metod nauczania; podejście do nauczania w sposób badawczy; możliwość uczenia innowacji; przekazywanie nowoczesnych technik; satysfakcja $\mathrm{z}$ pracy na nowoczesnych platformach edukacyjnych. Z kolei z perspektywy studenta e-learning to: atrakcyjne urozmaicenie zajęć; możliwość nadrobienia zajęć w trybie online, zwłaszcza gdy się pracuje; sposobność uczenia się w wybranym przez siebie czasie i przestrzeni; szansa poznania formy nauczania innej od tradycyjnej; sposób na wypracowanie systematyczności w nauce ${ }^{23}$.

\section{Podsumowanie}

$\mathrm{W}$ trakcie prowadzonych zajęć $\mathrm{z}$ wykorzystaniem bezpłatnych aplikacji internetowych oraz platform e-learningowych autorka mogła stwierdzić, że studenci byli bardzo zainteresowani nowymi metodami dydaktycznymi. Chętnie zapoznawali się z nowymi aplikacjami i korzystali z możliwości ilustrowania swoich prac projektowych czy artykułów aplikacyjnymi elementami graficznymi.

22 Ankieta $\mathrm{nr} 20$.

${ }^{23}$ Ankiety nr 8, 10, 11, 15, 20. 
Po analizie efektywności prowadzonych zajęć w systemie blended learningu wraz z aplikacjami dydaktycznymi można określić korzyści i zagrożenia wynikające $\mathrm{z}$ wprowadzenia $\mathrm{w}$ dydaktyce nowych technologii. Do korzyści należy przede wszystkim unowocześnienie prowadzonych zajęć, większe zainteresowanie studentów niż w przypadku klasycznych metod dydaktycznych, możliwość bardziej zindywidualizowanej pracy, lepsze zapamiętywanie trudniejszych zagadnień dzięki ilustrowaniu ich w odpowiednich aplikacjach. Negatywne strony wykorzystywania nauczania zdalnego i nowoczesnych aplikacji dydaktycznych to brak systematyczności w pracy studentów (zależnie od osobowości uczących się), a także obawy związane $\mathrm{z}$ udostępnianiem danych osobowych przy logowaniu się do kolejnych aplikacji. Indywidualizacja prowadzonych zajęć online jest bardzo korzystna, jednak zajęcia stacjonarne uzupełniają pewne braki związane z ograniczeniem komunikacji bezpośredniej.

Nowoczesne metody nauczania z pewnością są bardziej atrakcyjne dla studentów. Internet to naturalne środowisko studentów, więc istnieje duże prawdopodobieństwo, że wiedza przekazywana za pomocą nowych mediów będzie przez nich lepiej przyswajana, a nauczanie stanie się bardziej efektywne. Nowe technologie zaczynają dominować we wczesnych formach edukacji. Otwarte kursy online to kolejna możliwość pozwalająca na naukę bez wychodzenia z domu. Otwarte kursy dostępne w Internecie przyczyniają się do znacznej popularyzacji zdalnego nauczania.

Efektywność nauczania w formule e-learningu/blended learningu jest duża, biorąc jednak pod uwagę starsze roczniki studentów/doktorantów. W nauczaniu zdalnym podstawą są odpowiedzialność, systematyczność, samodzielność w wyszukiwaniu źródeł wiedzy, a także uczciwość przy wykonywaniu zadań. Analizując efektywność zajęć prowadzonych w systemie blended learningu, autorka może stwierdzić, że jest ona satysfakcjonująca. Wszystkie zadania wgrywane na platformy są realizowane (zazwyczaj bez dużych opóźnień), studenci nie kopiują rozwiązań z sieci, sami kreatywnie rozwiązują problemy, tworzą biznesplany, prowadzą grupowe burze mózgów, stosują metody związane z design thinking. Stały kontakt ze studentami stwarza dodatkowe obowiązki dla wykładowcy, jednak jest to trud opłacalny. Średnia ocen z egzaminów z poszczególnych przedmiotów prowadzonych w formule blended learningu wzrosła do 4,5 (z przeciętnej 4,1-4,3). Wzrosła również średnia ocen od studentów dla wykładowcy. Dodatkowe komentarze zamieszczane w systemie USOS (w ramach ankiet ewaluacyjnych) sugerują, że studenci chcą zwiększenia liczby zajęć $\mathrm{w}$ formule zdalnej i są bardzo zadowoleni z dotychczasowych projektów zrealizowanych na platformach e-learningowych. 


\section{Bibliografia}

Dąbrowski M., E-learning w szkolnictwie wyższym, „Studia BAS” 2013, nr 3 (35), s. 203-211.

Garrison D.R., Vaughan N.D., Blended Learning in Higher Education: Framework, Principles, and Guidelines, Jossey-Bass, San Francisco 2008.

Hyla M., Przewodnik po e-learningu, Wolters Kluwer, Warszawa 2016.

Mokwa-Tarnowska I., E-learning i blended learning $w$ nauczaniu akademickim: zagadnienia metodyczne, Wydawnictwo Politechniki Gdańskiej, Gdańsk 2015.

Redlarski K., Garnik I., Zastosowanie systemów e-learningu w szkolnictwie wyższym, [w:] B.A. Basińska, I. Garnik (red.), Zarządzanie informacyjnym środowiskiem pracy, Wydział Zarządzania i Ekonomii Politechniki Gdańskiej, Gdańsk 2014.

Stecyk A., Abc eLearningu: system LAMS (learning activity management system), Centrum Doradztwa i Informacji Difin, Warszawa 2008.

Susfał M., Moodle: ćwiczenia praktyczne. Doceń e-learning z platforma Moodle, Helion, Gliwice 2013.

Szabłowski S., E-learning dla nauczycieli, Wydawnictwo Oświatowe FOSZE, Rzeszów 2009.

Ubachs G., E-xcellence. Quality Assessment for E-learning: A Benchmarking Approach, EADTU, Heerlen 2012.

Zieliński Z., E-learning w edukacji. Jak stworzyć multimedialna i w pełni interaktywna treść dydaktyczną, Helion, Gliwice 2015.

\section{Źródła online}

www.edmodo.com

https://moodle.org

https://moodle.com/about/ 